\title{
THE MOLECULAR BIOLOGY OF NORRIE'S DISEASE
}

\author{
G. BLACK ${ }^{1}$ and R. M. REDMOND ${ }^{2}$ \\ Oxford and London
}

\begin{abstract}
SUMMARY
The Norrie's disease gene has been accurately located on the short arm of the $X$ chromosome. The methodology underlying this achievement and the structure of the three-exon gene is described in this review article. The clinical implications of these recent advances are discussed. Allelic variants of Norrie's disease and the phenomenon of females affected by $\mathrm{X}$-linked disease are also discussed.
\end{abstract}

Norrie's disease (NDP) ${ }^{1}$ was first described in $1927^{2}$ and, though rare, is well known as an X-linked disorder in which affected males have bilateral leucocoria evident in early infancy or even at birth. The leucocoria is due to a primary retinal dysplasia and resultant total retinal detachment. Such detachments are of early onset and have been observed by in utero ultrasonography ${ }^{3}$ (Fig. 1). Secondary glaucoma, cataract and eventual microphthalmos occur and are associated, in about one third of cases, with progressive sensorineural deafness. Mental retardation and psychotic behaviour in late childhood is a variable feature. ${ }^{4}$ Carrier females rarely have any biochemical, ocular or systemic abnormality.

In the past few years, huge progress has been made in our understanding of the disease through the application of modern molecular genetic techniques. This article surveys the progress made in our understanding of NDP and, in so doing, discusses some of the phenomena unique to the X-linked disorders.

\section{GENETIC MAPPING OF THE NDP GENE}

The NDP gene is located on the short arm of the X chromosome, close to the centromere. The disease locus lies within a region (Xp1 1.4-p1 1.3) to which other ocular diseases such as XL retinitis pigmentosa (XLRP), congenital stationary night blindness, XL cone dystrophy and XL familial exudative vitreoretinopathy also map (Fig. 2).

Since 1985, a series of linkage studies and deletion

From: 'Genetics Laboratory, Department of Biochemistry, South Parks Road, Oxford, UK; 'Moorfields Eye Hospital, City Road, London, UK.

Correspondence to: Mr R. M. Redmond, Moorfields Eye Hospital, City Road. London EC1V 2PD, UK.

Eye (1994) 8, 491-496 C 1994 Royal College of Ophthalmologists studies on a number of affected pedigrees have mapped the gene with increasing accuracy (Fig. 3). Tight linkage was described to the DNA probe L1.28 (often referred to as the $\mathrm{X}$ chromosome marker, DXS7). Linkage implies that two genetic loci are transmitted together through the generations of a pedigree more often than would be expected by chance - tightly linked loci are physically very close on the same chromosome. By observing meiotic recombination events between the accurately located DXS7 locus and the unknown NDP locus, it was calculated that the two were highly likely to lie within approximately 1 megabase ( $1 \mathrm{Mb}$, one million nucleotide base pairs) of one another.

Several patients have been described with proximal Xp deletions which include the DXS7 locus ${ }^{6}$ or with submicroscopic deletions involving the monoamine oxidase genes MAOA \& B. ${ }^{7}$ DNA polymorphisms within MAOA $\& \mathrm{~B}^{8}$ are therefore also closely linked to NDP and their use as DNA markers in informative pedigrees has enabled more accurate carrier risk estimation and the ability either to diagnose or to exclude Norrie's disease in the male fetus of a carrier female.

The search for more closely linked DNA markers which flank the gene in effect 'brackets' the gene locus, and allows the application of techniques that examine gen-

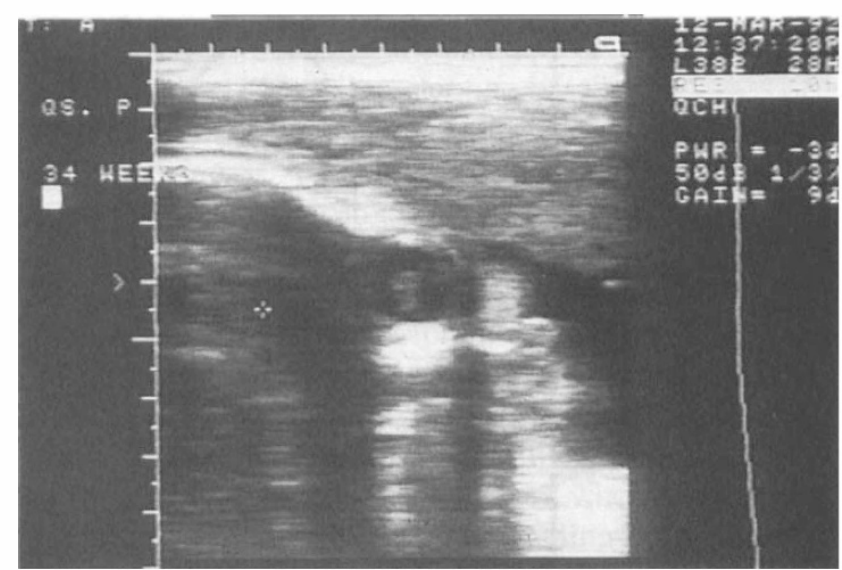

Fig. 1. In utero ultrasound scan of male fetus at 34 weeks. Total retinal detachment is evident (By kind permission of Aeolus Press.) 


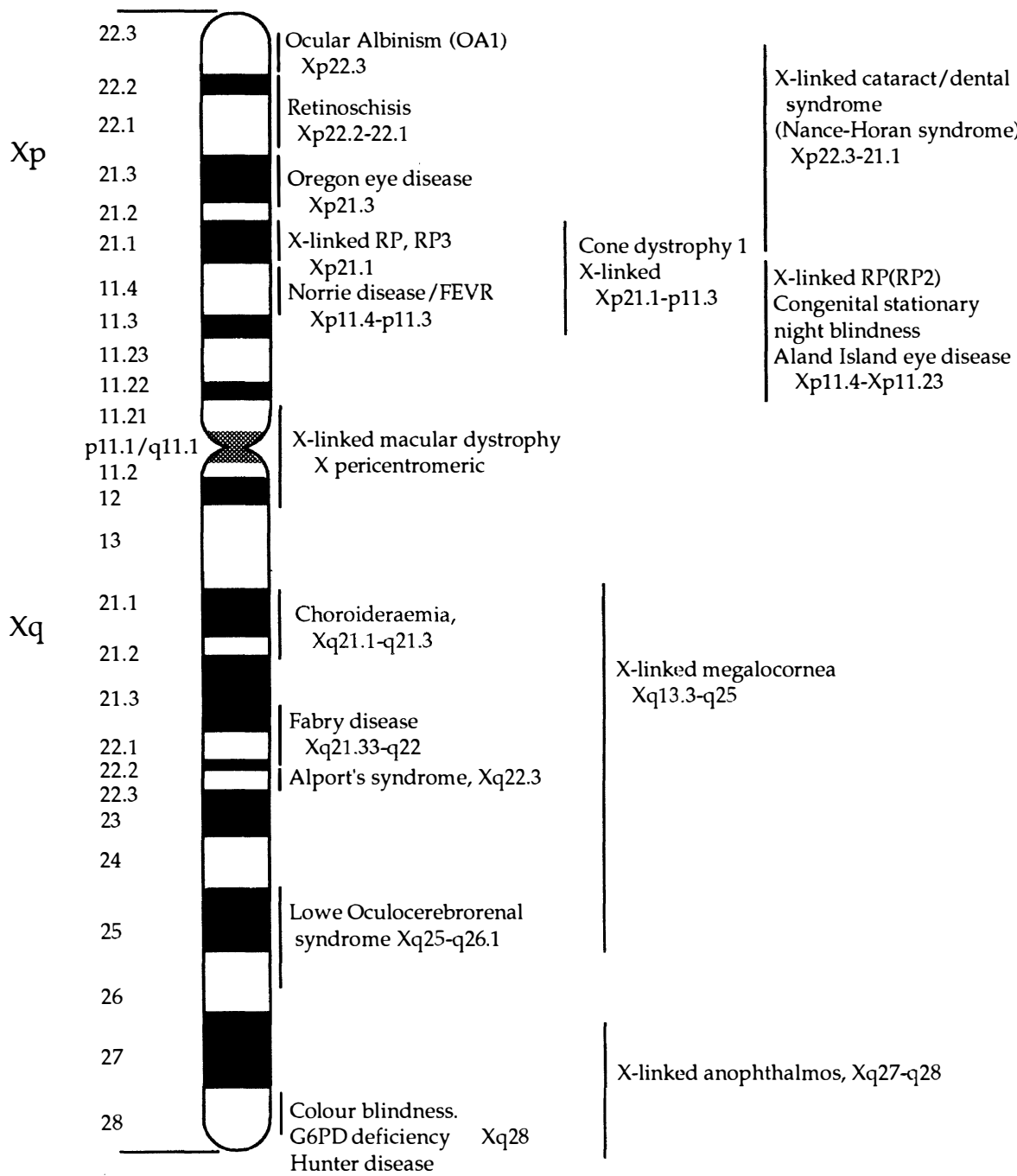

Fig. 2. Regional mapping of X-linked ophthalmic diseases.

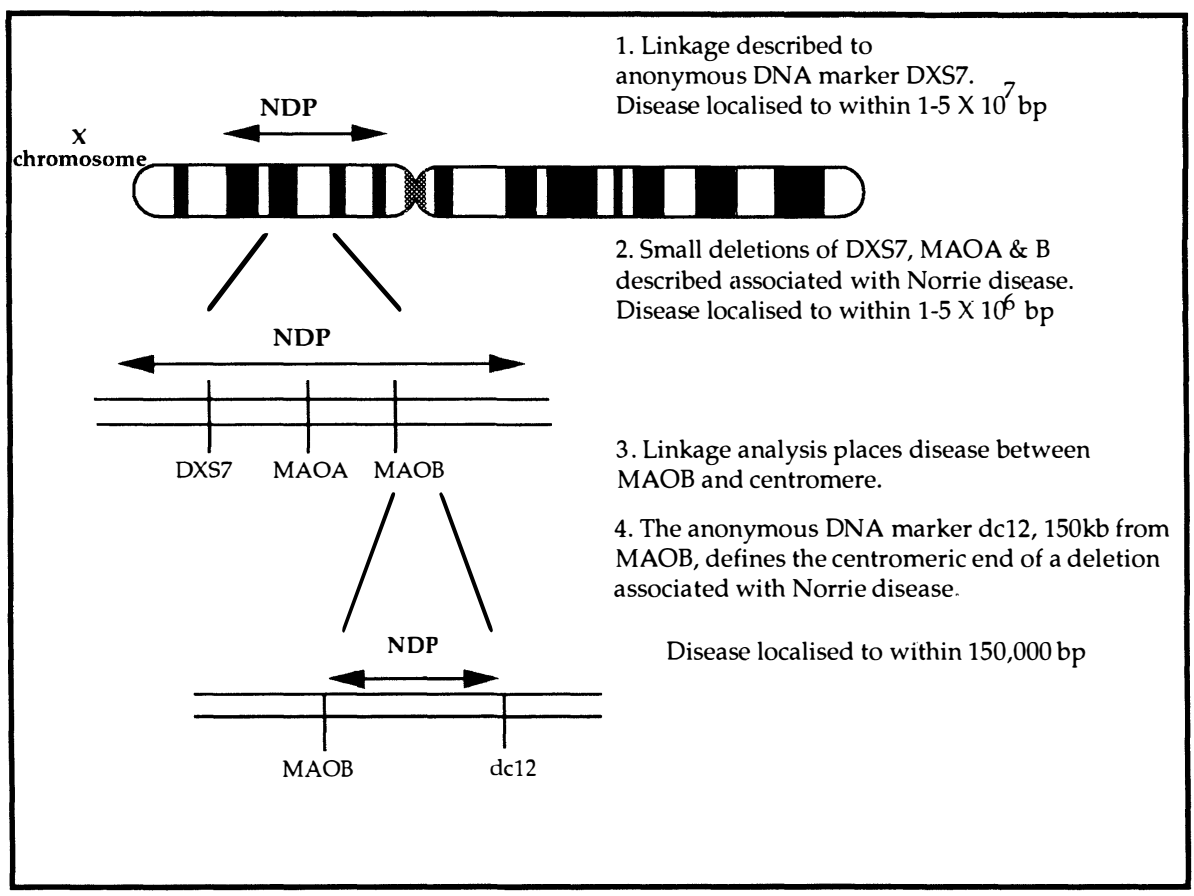

Fig. 3. Localisation of the Norrie disease gene. 


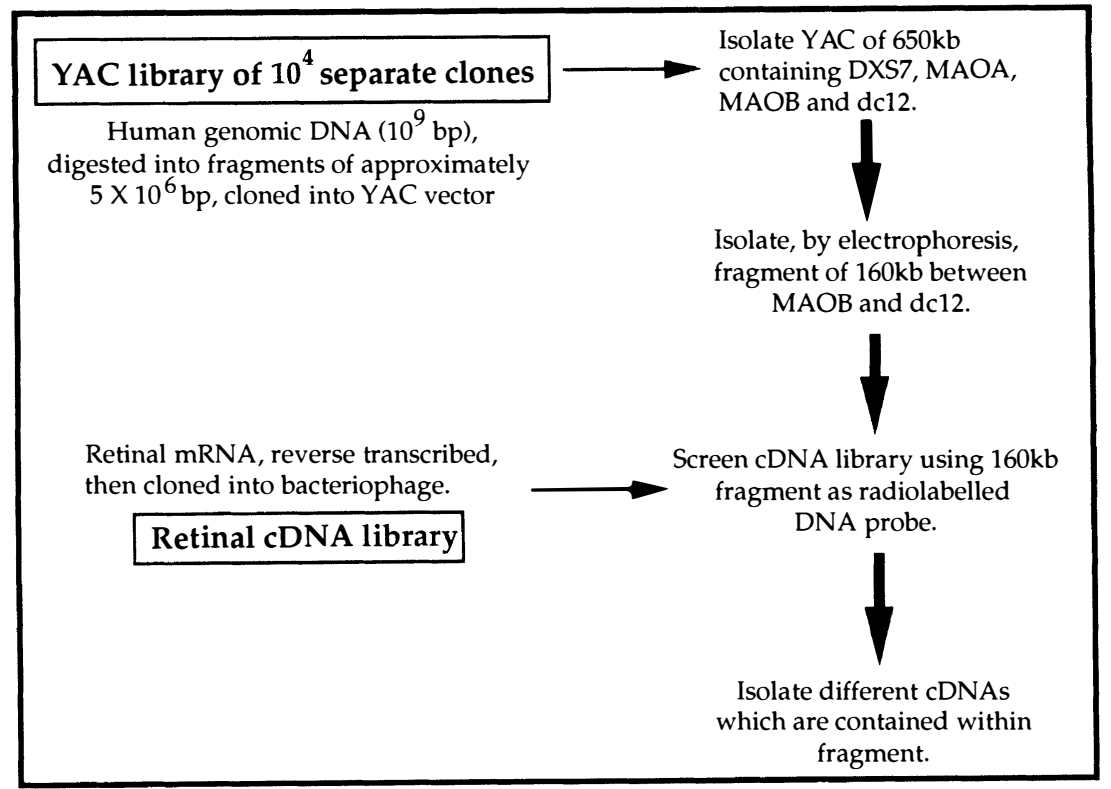

Fig. 4. Isolation of the Norrie disease gene.

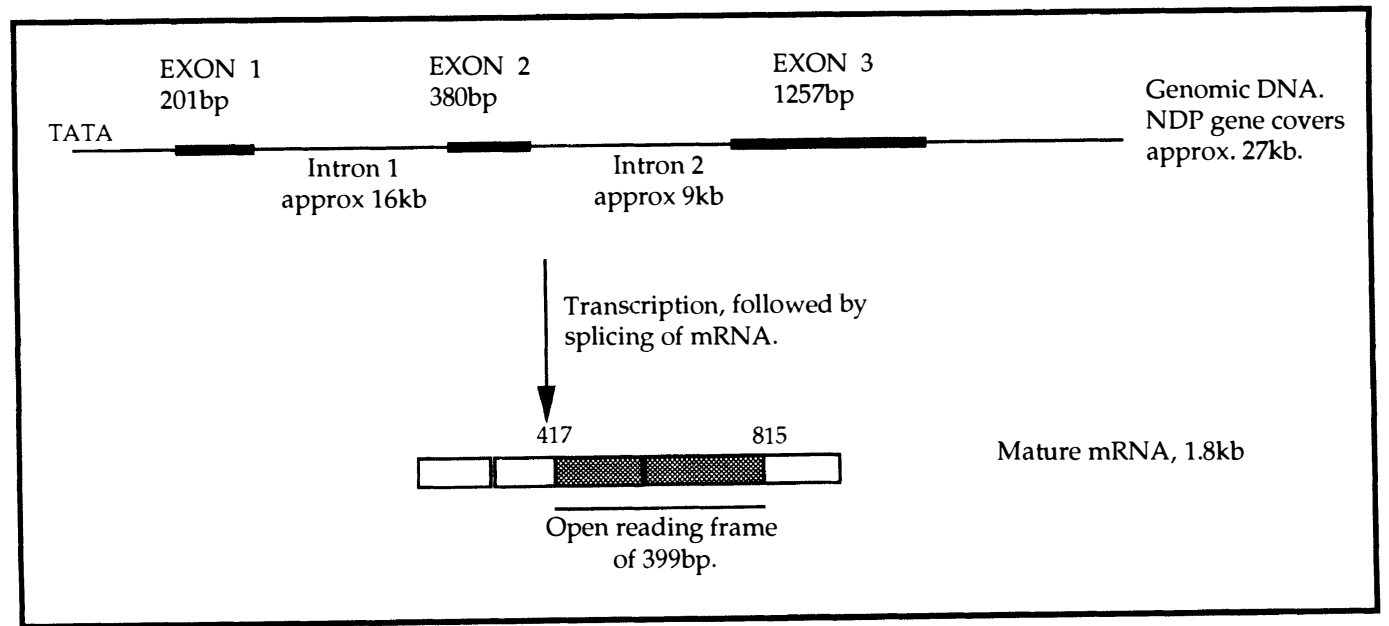

Fig. 5. Structure of the Norrie disease gene.

omic nucleotide sequences between the markers to identify the characteristics of a functional gene - the candidate gene.

\section{PHYSICAL MAPPING AND CLONING OF THE NDP GENE}

There are two complementary approaches to the cloning of disease genes; functional cloning and positional cloning. ${ }^{9}$ The former refers to a procedure in which a protein, previously isolated and characterised, is implicated in the aetiology of a disease and is used as the starting point for the isolation of the gene which encodes it. As no protein was previously implicated in the development of Norrie's disease, the method of functional cloning was not applicable to the search for the gene involved.

Positional cloning, however, is feasible once a Mendelian disorder (i.e. one due to a defect in a single gene) has been mapped genetically using closely linked DNA markers and the disease gene localised to a specific chro- mosomal region. In the case of Norrie's disease, the mapping of deletions, together with data from linkage analysis, led to accurate localisation of the NDP gene within $150 \mathrm{~kb}$ (150000 nucleotide base pairs). ${ }^{8}$

The next step required the utilisation of a specialised vector, the Yeast Artificial Chromosome (YAC) and a screening procedure using complementary DNA (cDNA) libraries from human retina ${ }^{10}$ (Fig. 4). cDNA libraries are derived from the messenger RNA (mRNA) of a specific tissue; the reverse transcription of the tissue-specific mRNA is accomplished with enzymes and the unique DNA sequences are then spliced into the DNA of a host vector (e.g. bacteriophage) which allows storage and subsequent retrieval of the cloned cDNA when required.

Chen et al. ${ }^{11}$ isolated a YAC containing DXS7, MAOA $\& \mathrm{~B}$ and NDP and obtained from it, by means of restriction enzymes and specialised electrophoresis, a $160 \mathrm{~kb}$ fragment of DNA believed to contain all or part of the NDP gene. This was used to isolate several cDNAs from libraries derived from fetal and adult retinal mRNA. Of 


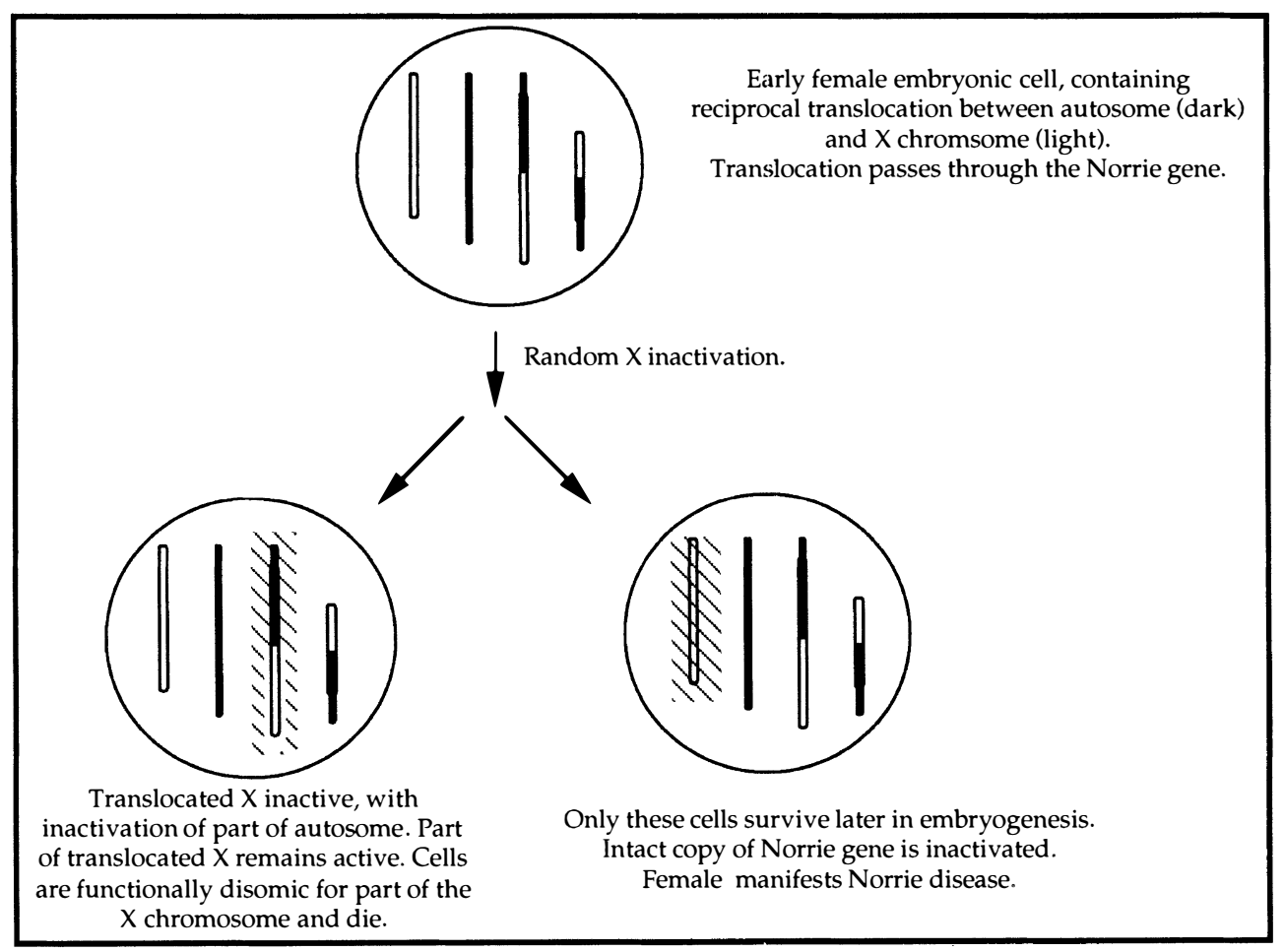

Fig. 6. Manifestation of X-linked disease in females with X:autosome translocation.

particular interest was one clone which was shown to hybridise to digests from a wide variety of organisms, including species as distant as the fruit-fly Drosophila. This suggested that evolution has maintained the DNA sequence in different species (it is said to be highly conserved) and indicates its probable importance to these organisms. The cDNA detected deletions in several affected males - including some not previously known to have deletions - and was therefore identified as a candidate gene for Norrie's disease.

\section{NDP GENE STRUCTURE AND PROTEIN PRODUCT}

The NDP gene is small and has three exons, the first of which does not code for any portion of the final protein product (i.e. it is not translated). ${ }^{10}$ Within exons 2 and 3 there is an open reading frame of 399 bp which encodes a protein chain of 133 amino acids (Fig. 5). As with many other ocular genes, NDP is expressed in extraocular tissues and has been shown to be expressed in adult and fetal brain, fetal lung and adult muscle.

Seventy-five per cent of point mutations observed have occurred in exon 3, although intrafamily variation in phenotype makes it difficult to correlate physical signs in affected males with mutation position. However, some cases with atypical Norrie's phenotype have large deletions and may be examples of a contiguous gene syndrome. $^{6}$ The altered phenotype may be the result of co-deletion of the MAO loci as well as other, as yet undefined, genes.

The encoded protein has homology to a protein domain thought to be involved in cellular adhesion. ${ }^{12}$ Other proteins which share homologous regions include mucins (a family of extracellular proteins), the Drosophila slit protein (an extracellular protein involved in glial development) and von Willebrand coagulation factor. These proteins show conservation of cysteine residues suggesting that they share an identical arrangement of disulphide bridges. More recent comparative studies indicate that the NDP protein shares homology and a predicted threedimensional structure with a carboxy-terminal domain (termed the cysteine knot) found as a component in a variety of cysteine-rich neurotrophins such as transforming growth factor (TGF) and nerve growth factor. ${ }^{13}$ On this basis it has been predicted that the dimerisation of the NDP protein may be an essential element in providing the recognition signals for targeting of neuronal/retinal connections.

\section{X-LINKED DISEASE AND AFFECTED FEMALES}

Most X-linked disorders characteristically affect only males. Carrier females are unaffected but may be distinguishable clinically as in the cases of XLRP, ocular albinism and choroideraemia. In certain circumstances, however, X-linked diseases may actually manifest in the female. In so-called X-linked dominant disorders (such as incontinentia pigmenti and pyruvate dehydrogenase deficiency) the effects are so severe that males rarely survive and the disorders manifest in heterozygous females. On rare occasions a female may be homozygous for an $\mathrm{X}$-linked disease locus (or in Turner's syndrome, hemizygous $\mathrm{XO}$ ) and will therefore manifest the disease.

Another mechanism leading to an X-linked disease occurring in a female is unbalanced $\mathrm{X}$ chromosome inactivation. In order to equalise the genetic contribution 
of the sex chromosomes in the two sexes, all female somatic cells inactivate one $\mathrm{X}$ chromosome, a process termed Lyonisation. ${ }^{14}$ Although a random process, selection or chance may result in biased inactivation towards one $X$ chromosome. Should a mutation-carrying X chromosome be active in a sufficient proportion of cells in the tissue in which a gene is expressed then a female may manifest the disease. A family with Norrie's disease has been investigated in which an obligate carrier female had two affected children, one male and one female. ${ }^{15}$ Measurements of the $\mathrm{X}$-inactivation ratio in the affected daughter suggested that in her peripheral lymphocytes a majority of cells had the mutant $\mathrm{X}$ chromosome active. It is likely that this phenomenon, a chance event, is paralleled in her retinal cells and accounts for her manifestation of the disease.

Another female has been described with Norrie's disease associated with a reciprocal $X$ :autosome translocation $\mathrm{t}(\mathrm{X}: 10)(\mathrm{p} 11: \mathrm{p} 14) .{ }^{16}$ Females suffering from many $\mathrm{X}$-linked diseases as a result of $\mathrm{X}$ :autosome translocations have now been described. In these cases, those cells which have inactivated the translocated $\mathrm{X}$ chromosome will have a partial autosomal monosomy and a partial X chromosome disomy and will not survive. ${ }^{17}$ In the case of the female with Norrie's disease it is assumed that the translocation passes through the Norrie's disease locus and, as all her cells have that $\mathrm{X}$ chromosome remaining active, none will have an active, intact copy of the gene (Fig. 6).

\section{ALLELIC VARIANTS OF NORRIE'S DISEASE; X-LINKED FAMILIAL VITREORETINOPATHY}

Linkage to the region around the NDP locus has been described for two other related disorders: X-linked familial vitreoretinopathy (FEVR) ${ }^{18}$ and X-linked retinal dysplasia. ${ }^{19}$ The familial exudative retinopathies are a small group of disorders and both autosomal and X-linked forms are described. They are characterised by a variable picture of retinal folds, fibrovascular masses, white intraretinal deposits, subretinal exudates and retinal detachment. Some individuals have subclinical disease, others develop symptomatic changes in early adulthood and still others develop phthisis bulbi, end-stage disease. The X-linked form is the least common with few reported pedigrees. $\mathrm{X}$-linked retinal dysplasia is a rare disorder with retinal folds, nystagmus and early-onset blindness in males.

Recently, a mutation in exon 3 of the NDP gene, which is not seen in normal controls, has been described in all affected individuals in one family with FEVR. ${ }^{20}$ This suggests that different retinal phenotypes may be associated with mutations in the NDP gene, a situation now recognised for a variety of other retinal proteins; autosomal dominant (ADRP) and sectoral RP, autosomal recessive $\mathrm{RP}$ and congenital stationary night blindness have all been shown to be associated with rhodopsin mutations. ${ }^{21-23}$ Mutation analysis in patients with a variety of inherited retinal disorders has now led to the peripherin protein being implicated in the aetiology of ADRP, ${ }^{24}$ adult vitelliform macular dystrophy, ${ }^{25}$ autosomal dominant retinitis punctata albescens ${ }^{26}$ and butterfly-shaped pigment dystrophy. ${ }^{27}$ It is likely that in the future the classification of these inherited retinal and ocular disease phenotypes will rely on DNA molecular analysis as well as clinical assessment.

\section{CONCLUSIONS}

In the past two to three years huge advances have been made, through molecular genetics, in our understanding of Norrie's disease. In a short space of time we have progressed from a knowledge of the approximate position of the gene through linkage analysis to a detailed understanding of the gene, its mutations and the associated phenotypes. As a result, we are now beginning to understand the chemistry of the protein which it encodes and, although much is still to be learned in this field, it is to be hoped that we will soon understand how defects of this gene cause retinal dysplasia.

With the explosion in the number of described, mapped and highly informative DNA polymorphisms it is now possible to define whether a child (born or unborn) has inherited a disease-causing mutation. This system of analysis does have limitations. First, a given polymorphic locus may not demonstrate differences between individuals in the family under examination, i.e. it may be uninformative. Second, in general, for this type of analysis to be reliable, a fairly large number of individuals from a family need to be analysed. However, the cloning of a disease gene allows direct detection of a mutation and whole pedigrees need not be examined. An affected individual's DNA may be all that is required. Once a mutation has been detected, then carrier detection and prenatal diagnosis for the rest of the family is relatively simple and extremely reliable. Norrie's disease, with a relatively small gene and most mutations localised to one exon, is now in this category.

As more and more of the genes involved in the pathogenesis of ophthalmic diseases are identified, this will allow a new level of understanding of their pathogenesis and also, perhaps more interestingly, of ocular development and biochemistry. In the short term this will allow improvements to be made in diagnosis, prenatal diagnosis and in the assessment of prognosis. It is to be hoped that this may in turn lead to progress in treatment, both conventional and perhaps genetic.

Key words: Gene cloning, Leucocoria, Retinal dysplasia.

\section{REFERENCES}

1. McKusick V. Mendelian inheritance in man, vol 10. Baltimore and London: Johns Hopkins University Press, 1992.

2. Norrie G. Causes of blindness in children. Acta Ophthalmol (Copenh) 1927:5:357-86.

3. Redmond R, Vaughan J, Jay M, Jay B. In utero diagnosis of Norrie disease by ultrasonography. Ophthalmic Paediatr Genet 1993;141:1-3.

4. Warburg M. Norrie's disease, a congenital progressive oculo-acoustico-cerebral degeneration. Acta Ophthalmol Suppl (Copenh) 1966;89:1-149. 
5. Gal A, Bleeker-Wagemakers EM, Wienker TF, Warburg M, Ropers HH. Localisation of the gene for Norrie disease by linkage to the DXS7 locus [abstract]. Cytogenet Cell Genet 1985;40:633.

6. de la Chapelle A, Sankila E-M, Lindlof M, Aula P, Norio R. Norrie disease caused by a gene deletion allowing carrier detection and prenatal diagnosis. Clin Genet 1985;28:317-20.

7. Sims KB, de la Chapelle A, Norio R, Sankila E-M, Hsu $\mathrm{Y}-\mathrm{P}$, Rinehart WB, et al. Monoamine oxidase deficiency in males with an $\mathrm{X}$ chromosome deletion. Neuron 1989;2:1069-76.

8. Sims KB, Lebo RV, Benson G, Shalisk C, Schuback D, Chen $\mathrm{Z}-\mathrm{Y}$, et al. The Norrie disease gene maps to a $150 \mathrm{~kb}$ region on chromosome Xp1 1.3. Hum Molec Genet 1992;1:83-9.

9. Collins FS. Positional cloning: let's not call it reverse anymore. Nature Genet 1992;1:3-6.

10. Berger W, Meindl A, van de Pol TJR, Cremers FPM, Ropers $\mathrm{HH}$, Doerner $\mathrm{C}$, et al. Isolation of a candidate gene for Norrie disease by positional cloning. Nature Genet 1992;1:199-203.

11. Chen Z-Y, Sims SB, Coleman M, Monaco A, Breakefield $\mathrm{XO}$, Davies KE, Craig IW. Characterization of a YAC containing part or all of the Norrie disease locus. Hum Molec Genet 1992;1:161-4.

12. Meindl A, Berger W, Meitinger T, van den Pol D, Achatz H, Dorner $\mathrm{C}$, et al. Norrie disease is caused by mutations in an extracellular protein resembling C-terminal globular domain of mucins. Hum Molec Genet 1992;2:139-43.

13. Meitinger T, Meindl A, Bork P, Rost B, Sander C, Haasemann M, Murken J. Molecular modelling of the Norrie disease protein predicts a cystine knot growth factor tertiary structure. Nature Genet 1993;5:376-80.

14. Lyon MF. Gene action in the X-chromosome of the mouse (Mus musculus L.). Nature 1961;190:372.

15. Chen Z-Y, Battinelli EM, Woodruff G, Young I, Breakefield $\mathrm{XO}$, Craig IW. Characterisation of a mutation within the NDP gene in a family with a manifesting female carrier. Hum Mol Genet 1993;2:1727-9.

16. Ohba N, Yamashita T. Primary vitreoretinal dysplasia resembling Norrie's disease in a female: association with $\mathrm{X}$ autosome chromosomal translocation. $\mathrm{Br} \mathrm{J}$ Ophthalmol 1986;70:64-71.

17. Schmidt M, Du Sart D. Functional disomies of the X chro- mosome influence the cell selection and hence the $\mathrm{X}$ inactivation pattern in females with balanced $X$-autosome translocations: a review of 122 cases. Am J Med Genet 1992;42:161-9.

18. Fullwood P, Jones J, Bundey S, Dudgeon J, Fielder AR, Kilpatrick MW. X-linked exudative vitreoretinopathy: clinical features and genetic linkage analysis. Br J Ophthalmol 1992;77:168-70.

19. Ravia Y, Braier-Goldstein O, Bat-Miriam KM, Erlich S, Barkai G, Golman B. X-linked recessive primary retinal dysplasia is linked to the Norrie disease locus. Hum Mol Genet 1993;2:1295-7.

20. Chen Z-Y, Hendriks RW, Jobling MA, Powell JF, Breakefield XO, Sims KB, Craig IW. Mutations in the Norrie gene associated with FEVR. Nature Genet 1993;1:204-8.

21. Inglehearn CF, Keen JT, Bashir R, Jay M, Fitzke F, Bird AC, et al. A completed screen for mutations of the rhodopsin gene in a panel of patients with autosomal dominant retinitis pigmentosa. Hum Molec Genet 1992;1:41-5.

22. Rosenfeld PJ, Cowley GS, McGee TL, Sandberg MA, Berson EL, Dryja TP. A Null mutation in the rhodopsin gene causes rod photoreceptor dysfunction and autosomal recessive retinitis pigmentosa. Nature Genet 1992;1:209-13.

23. Dryja TP, Berson EL, Rao, VR, Opsian DD. Heterozygous missense mutation in the rhodopsin gene as a cause of congenital stationary night blindness. Nature Genet 1993; $4: 280-3$.

24. Farrar GJ, Kenna P, Jordan SA, Kumar-Singh R, Humphries MM, Sharp EM, et al. A three base-pair deletion in the peripherin-RDS gene in one form of retinitis pigmentosa. Nature 1991;354:480-3.

25. Wells J, Wroblewski J, Keen J, Inglehearn C, Jubb C, Eckstein $\mathrm{A}$, et al. Mutations in the human retinal degeneration slow $(R D S)$ gene can cause either retinitis pigmentosa or macular dystrophy. Nature Genet 1993;3:213-8.

26. Kajiwara K, Sandberg MA, Berson EL, Dryja TP. A null mutation in the human peripherin/RDS gene in a family with autosomal dominant retinitis punctata albescens. Nature Genet 1993;3:208-12.

27. Nichols BE, Sheffield VC, Vandenburgh K, Drack AV, Kimura AE, Stone EM. Butterfly-shaped pigment dystrophy of the fovea caused by a point mutation in codon 167 of the RDS gene. Nature Genet 1993;3:202-7. 